\title{
Lean university: applying the ECRS method to improve an administrative process
}

\author{
Raluca Mihaela Bârsan ${ }^{1,}$, and Felicia-Mihaela Codrea ${ }^{1}$ \\ ${ }^{1}$ Lucian Blaga University of Sibiu, Romania
}

\begin{abstract}
This paper presents a case study for an improvement method applied in "Lucian Blaga" University of Sibiu, Romania. The ECRS method has its roots in manufacturing, specifically in improvement processes. The novelty lies in applying this method in Higher Education. Considering the existing know-how in process improvements of the human resource from the University and the importance of quality in the organisation's performance, this paper sought to focus on using one of the most important principles of lean manufacturing in the administrative sector. An observation form was designed in order to analyse the process and by using the ECRS method and brainstorming for ideas with key stakeholders, the time needed by final-year students in order to complete the "University check-out" form was reduced.
\end{abstract}

\section{Introduction}

First significant improvements in the manufacturing sector began in 1901 with the arrival of the first assembly line. Henry Ford then introduces the mass production system, which will later be analysed by Kiichiro and then Eiji Toyoda (from Toyota company), leading them to introduce the Toyota Production System (TPS). Although Toyota applied and developed the improvement methods so popular in today's automotive industry (like Kanban, JIT, TPS), it was only in 1990 that the term lean manufacturing was first introduced with the publishing of the book "The Machine that Changed the World" [1].

From the three categories in focus of lean manufacturing: productivity, quality and waste elimination, this paper is interested in the latter and how this could also be applied to administrative processes, not just assembly [2,3]. Even before the introduction of the term lean manufacturing, Edwards Deming gave lectures and held trainings regarding key quality principles, convincing top managers in manufacturing companies but also many service organizations to adopt a new approach to performance [4].

Based on a focus group comprised of former "Lucian Blaga" University of Sibiu students, we chose the "University check-out" form as the focus point in our study. In order to receive a "degree substitute" (until the actual degree is printed, signed, stamped and approved by the Ministry of Education), students had to fill out a feedback questionnaire and receive various confirmation signatures on a check-list-like form. Students in the focus group argued that this was a process that took quite long as they had to print the form and

* Corresponding author: raluca.roca@ulbsibiu.ro 
personally take it to each location on the initially 8-point long checklist. Although the time estimations for this process varied from student to students during the focus group, all agreed that they needed to free-up half a day in order to complete the checklist in all locations (considering working hours of different departments involved).

\section{Research methodology}

ECRS is one of the motion study techniques used to analyse processes in a production line. ECRS analyses processes and activities using the following core principles: $\mathrm{E}=$ Eliminate unnecessary work $\mathrm{C}=$ Combine operations $\mathrm{R}=$ Rearrange sequence of operations $\mathrm{S}=$ Simplify the necessary operations [5]. Considering the previous research from literature reviews it can be stated that ECRS is a simple and effective method used in manufacturing for improving efficiency of production lines. Awapak et al. [6] used ECRS technique and single minute exchange of die (SMED) method to reduce idle time during the ice-cream making process. Miranda [7] proposed to adopt ECRS in increasing man efficiency of the clean room assembly process that influenced the reduction of manpower costs of one electronics manufacturer in Philippines. Makprang [8] applied ECRS to reduce the total internal transportation distance and number of operators of the canned fruits production line. Kasemset et al.[9] adopted ECRS to reduce negative product cost from defects of one plastics packaging factory in Thailand. Thus, ECRS used as an improvement tool can be used also in administrative processes given the fact that the main aim of this method is to reduce the non-value adding activities.

In Romanian literature reviews, the "R" in ECRS is in some cases replaced with an "I" (for Improve) and the method is used in forms that analyses the process flow for a part. In order to visualize the state of each work sequence, from an added value / waste point of view, one model chose 5 symbols: Technological process $=\mathrm{O}$, Quality control = Transport $==>$, Waiting $=\mathrm{D}$ and Storing $=\Delta$. As opposed to this model presented by Liviu Moldovan in chapter 5 of the book "Manual de inginerie economica: Planificarea si organizarea facilitatilor de productie" [10], an Excel model adaptation was developed by choosing to represent the degree of value added in the process, the transport, waiting and searching contained in each step of the analysed process. We considered the database checks could have been considered similar to the quality control symbol in the model, but as this does not really add any added value to the process analysed and this is also quite impossible to eliminate for now, we chose to omit this type of waste and introduced the searching, as we found this to be quite frequent. Storing was also omitted as the old process implied each student had to fill in his name and personal id number on the "check-out" form and take it separately to each office. No storing would take place in this case.

\begin{tabular}{|c|c|c|c|c|c|c|c|c|c|c|c|c|c|}
\hline \multirow{3}{*}{ Process steps } & \multicolumn{6}{|c|}{ Initial state } & \multicolumn{6}{|c|}{ Target state } & \multirow{3}{*}{ Notes } \\
\hline & \multicolumn{2}{|c|}{ Duration: } & \multicolumn{4}{|c|}{ Contains: } & \multicolumn{2}{|c|}{ Duration: } & \multicolumn{4}{|c|}{ Analysis: } & \\
\hline & $\begin{array}{c}t \\
{[s]}\end{array}$ & $\begin{array}{c}\mathrm{d} \\
{[\mathrm{m}]}\end{array}$ & Added value & Transport & Search & Wait & $\begin{array}{c}\mathrm{t} \\
{[\mathrm{s}]}\end{array}$ & $\begin{array}{c}\mathrm{d} \\
{[\mathrm{m}]}\end{array}$ & $\mathbf{E}$ & $\mathbf{C}$ & $\mathbf{R}$ & $\mathbf{S}$ & \\
\hline
\end{tabular}

Fig. 1. ECRS analyse form

In order to eliminate waste, it is essential to identify the value adding and non-value adding activities in a process. We considered the activities that led to the student obtaining the signed "check-out form" as value adding and the rest as necessary or unnecessary waste to be reduced or eliminated. We chose to use ECRS to help us focus on breaking down each step into possible future improvements and extracting the value from the process. We simulated the entire process for one student in order to get an idea about the activities needed for each step and a mean time for the whole process. A stopwatch was used in the 
simulation, not in order to time the personnel performing the job, but in order to see the ratio between value adding and non-value adding activities and estimate the possible benefits / urgency of the proposed solutions.

As stated above, every action that did not require elimination, combination, rearrangements or simplification and which visibly contributed to the final objective (completing the "check-out form") was considered value adding. Each location on the "check-out form" needed to be visited by each student, so this step alone implied the student needed to go a certain distance to the requested location and wait for the check to be performed before he/she would receive the "green light" stamp. This was one of the biggest wastes identified in the "University check-out" process: transport. A student would have to complete an average distance of $10,25 \mathrm{~km}$. Although the distances vary according to location on the "checklist", all locations needed to be visited and none of the checks could be performed online or remote from the faculty. This was the first question mark for us to find out if the databases needed for each check could not be integrated into the same system. The second question that came to mind was, if the databases are separate, why should each student personally take the form to each location? $10,25 \mathrm{~km}$ for one student may not seem so extreme, but multiplied with the total number of 4-year and final-year masters students, the number becomes increasingly important. Simulating the process from start to finish for one student helped us identify other types of waste.

\section{Results}

First of all, searching for the form and filling out the name, personal ID number and type of student is no longer needed. When the form is printed, the name and identification information of the student is automatically filled out. Secondly, there was a big reduction from 8 points to 4 points on the checklist to be stamped. This was however not done as a result of the initial ECRS analysis. In trying to implement a lean improvement, we omitted the most important step in any improvement process: talking to the process owner. Towards the end of our simulation we found out that the form found by the students on the University website was no longer valid and that a new "check-out form" had been implemented. The simulation turned into an important lesson learned in this area, thus we decided to continue the initial analyse and compared the outcome of our initial observations with the improvements already implemented by the University in the meantime. The focus of the analysis was not the results from the time keeping, but the ratio between value and non-value adding activities and observation of the process steps. Asking if some steps are truly needed and eliminating unnecessary checks is the first step and the most important principle in quality improvements.

One of the first questions raised by the authors was also the first question of the process owner (regarding the use of multiple databases). This is a limitation that could not be solved for now, as it is a stand-alone future project. However, the biggest waste with transporting the form by each student from one point to the other has been eliminated. This was the main improvement together with the reduction from 8 to 4 points on the checklist.

After sharing the results of both analyses, the common conclusion was that this current best practice in the University could still be improved and by discussing the current limitations and ideas with the process owner we came up with a new solution and best practice: transferring all information regarding student debits, library loans and so on to the students access card. Thus, when the student hands in his card, this is scanned and all information regarding his status is shown. No more transporting documents, unnecessary printing of paper, searching for buildings or offices or waiting. If the status of the card is ok for all aspects, only one paper should be printed with the student name on it: the temporary "degree substitute". 
Table 1. Old check-out form steps analyse.

\begin{tabular}{|c|c|c|c|c|}
\hline \multirow{3}{*}{ Process steps } & \multicolumn{4}{|c|}{ Initial state - old check-out form } \\
\hline & \multicolumn{4}{|c|}{ Step contains: } \\
\hline & $\begin{array}{c}\text { Added } \\
\text { value }\end{array}$ & Transport & Search & Wait \\
\hline $\begin{array}{l}\text { 1. Go to University library for final } \\
\text { status check and stamp }\end{array}$ & $1 \mathrm{~min}$ & yes $\mathrm{x} 2$ & & yes \\
\hline $\begin{array}{l}\text { 2. Go to Faculty library for final status } \\
\text { check and stamp (only for engineers) }\end{array}$ & $1 \mathrm{~min}$ & yes & & yes \\
\hline $\begin{array}{l}\text { 3. Go to Faculty administrator for final } \\
\text { status check and stamp }\end{array}$ & $1 \mathrm{~min}$ & yes & yes & yes \\
\hline $\begin{array}{l}\text { 4. Go to Dorms administrator for final } \\
\text { status check and stamp }\end{array}$ & $1 \mathrm{~min}$ & yes $\mathrm{x} 2$ & yes & yes \\
\hline $\begin{array}{l}\text { 5. Go to Social Services Office for final } \\
\text { status check and stamp }\end{array}$ & $1 \mathrm{~min}$ & yes $\mathrm{x} 2$ & yes & yes \\
\hline $\begin{array}{l}\text { 6. Go to the Financial Office for final } \\
\text { status check and stamp }\end{array}$ & $1 \mathrm{~min}$ & yes & & yes \\
\hline $\begin{array}{l}\text { 7. Go to the Head of the Financial } \\
\text { Office for final status check and stamp }\end{array}$ & $1 \mathrm{~min}$ & yes & yes & yes \\
\hline $\begin{array}{l}\text { 8. Go to the Alumni and Orientation } \\
\text { Office for final status check and stamp }\end{array}$ & $10 \mathrm{~min}$ & yes $\mathrm{x} 2$ & & yes \\
\hline Total time needed & $17 \mathrm{~min}$ & $\begin{array}{c}\text { No } \\
\text { optimized } \\
\text { transport } \\
\text { route }\end{array}$ & yes & yes \\
\hline
\end{tabular}

Total process time is 7 times bigger than the value added time (the waste in the process is more than $85 \%$ ); there is too much redundant transport and the transport routes could be optimized if not completely eliminated; searching and waiting are also present in this process, affecting the efficiency of other processes by interrupting people from their jobs without a clear schedule for receiving students.

Table 2. Current check-out form steps analyse.

\begin{tabular}{|c|c|c|c|c|}
\hline \multirow{3}{*}{ Process steps } & \multicolumn{4}{|c|}{ Initial state - current check-out form } \\
\hline & \multicolumn{4}{|c|}{ Step contains: } \\
\hline & $\begin{array}{l}\text { Added } \\
\text { value }\end{array}$ & Transport & Search & Wait \\
\hline $\begin{array}{l}\text { 1. Sent to the Social Services Office for } \\
\text { final status check and stamp by the } \\
\text { Faculty }\end{array}$ & $1 \mathrm{~min}$ & $\begin{array}{c}\text { yes } \\
\text { (shortest } \\
\text { route) }\end{array}$ & no & no \\
\hline $\begin{array}{l}\text { 2. Sent by the Social Services Office to } \\
\text { the Financial Office for debts check and } \\
\text { stamp }\end{array}$ & $1 \mathrm{~min}$ & $\begin{array}{c}\text { yes } \\
\text { (same } \\
\text { building) }\end{array}$ & no & no \\
\hline $\begin{array}{l}\text { 3. Sent by the Financial Office to the } \\
\text { University library for final status check, } \\
\text { loans and stamp }\end{array}$ & $1 \mathrm{~min}$ & yes & no & no \\
\hline $\begin{array}{l}\text { 4. Sent by the library to the Alumni and } \\
\text { Orientation Office for final status check }\end{array}$ & $1 \mathrm{~min}$ & $\begin{array}{l}\text { yes } \\
\text { (same }\end{array}$ & no & no \\
\hline
\end{tabular}




\begin{tabular}{|c|c|c|c|c|}
\hline and stamp & & building) & & \\
\hline $\begin{array}{l}\text { 5. Student picks up stamped form from } \\
\text { the Alumni and Orientation Office after } \\
\text { completing an online questionnaire and } \\
\text { brings form to the Faculty to receive } \\
\text { "degree substitute" }\end{array}$ & $10 \mathrm{~min}$ & yes & no & maybe \\
\hline Total time needed & $14 \min$ & $\begin{array}{l}1 \text { transport } \\
\text { trip for the } \\
\text { student } \\
\text { and } \\
\text { improved } \\
\text { route for } \\
\text { the } \\
\text { document }\end{array}$ & - & limited \\
\hline
\end{tabular}

Total process time was reduced; waste with searching (for students) was eliminated (as the form is passed internally from one office to the next); waiting time was reduced (as the student does not have to take the form to each point) and transport routes were also improved and reduced.

The starting point was searching for the form on the University or Faculty website. Searching and waiting are part of the 7-types of Waste, so we considered this time as nonvalue adding and proposed to reduce it. As a best practice, today, students don't need to search for this form online as it is printed by the Department secretary and sent to be checked by the Administrative Office, Financial Office and University Library. After debits and loan situations are checked, they are sent to the Orientation Office where the student can claim the form, after completing a feedback questionnaire.

\section{Conclusions and recommendations}

As the world becomes more complex, planning and prioritization of activities in Universities and the public sector will make the difference. The education system comprises also the administrative processes and is driven by small improvements made every day. Given the fact that we live in a world where knowledge and digital innovation is mandatory the education system needs to make a step toward the smart tools and use them wisely.

Given the fact that the expertise in continuous improvement exists in the University, it would be a huge loss not to use the know-how in improving the operations inside it besides developing projects for external organizations and the authors would recommend replicating this workshop for other areas, maybe even integrating this type of projects in the University curriculum.

Lean methods are important tools that help improve productivity in manufacturing companies, but more and more organisations focus on change management and continuous improvement to develop o strong organizational culture to foster lean methods and increase performance. It is not a matter for industry only anymore, but a question for leadership and performance everywhere.

An important future challenge, after implementing these so called "quick-wins" will come from continuing with improvements until the benefits from solving a problem still exceed the costs [11]. As technology becomes more sophisticated, the opportunities to help and improve grow day by day, but so do the costs. 


\section{References}

1. J. P. Womack, The Machine that Changed the World (1990)

2. B. Resta, S. Dotti, P. Gaiardelli, A. Boffelli, Lean Manufacturing and sustainability: an integrated view, In: Naas, 1., et al. (eds.), Adv. Prod. Manag. Sust. Initiat. a Sustain. World. APMS 2016. Springer, Iguassu, pp. 659-666 (2016)

3. R. Henao, W. Sarache, I. Gomez, Journal of Cleaner Production, 208, pp.99-116 (2019)

4. https://www.academia.edu/456546/Demings_Quality_Principles_A_Health_Care_App lication, retrieved on April 30th 2019.

5. C. Kasemset, P. Pinmanee, P. Umarin, Proceedings of the Asia Pacific Industrial Engineering \& Management Systems Conference, pp.1478 (2014)

6. D. Awapak, S. Pisuchpen, M. Ladsen, Proceedings of 49th Kasetsart University Annual Conference: Architecture and Engineering, pp.538 (2011)

7. F. Miranda, The 21 st ASEMEP National Technical Symposium (2011)

8. K. Makprang, C. Kasemset, A. Sopadang, Proceeding of the Value Chain Management and Logistics Conference, Chiang Mai, Thailand, pp.105-112 (2012)

9. C. Kasemset, S. Sasiopars, S. Suwiphat, Proceedings of the Institute of Industrial Engineers Asian Conference, Taiwan, pp.353-361 (2013)

10. M. Țuţurea, Manual de inginerie economică: Planificarea și organizarea facilităţilor de producție, pp.138 (2000)

11. R. Henao, W. Sarache, I. Gomez, Journal of Cleaner Production, 208, pp.99-116 (2019) 